\title{
Positive Word of Mouth and Profitability: The Experience of Banks in Port Harcourt - Nigeria
}

\author{
Bright ZorBari-Nwitambu, M.Sc. \\ Library Department, Ken Saro-Wiwa Polytechnic, Bori
}

\begin{abstract}
This paper focused on ascertaining the relationship that exists between positive word of mouth and profitability with emphasis on the banking sector's experience in Port Harcourt. It is a descriptive study that involved survey design hence, the use of 105 copies of questionnaire to gather primary data from top management cadre personnel of the 21 money deposit banks in Port Harcourt; secondary data were generated as well. Spearman correlation coefficient was used to analyze the data generated and to examine the relationship that existed between the studied variables, and were further regressed to ascertain the extent of their relationship using SPSS version 20.0 software. Conclusively, it was revealed that positive word of mouth significantly influenced profitability of banks in Port Harcourt. Consequently, it was recommended that banks in Port Harcourt should constantly strive to pursue customer satisfaction as this is key to achieving positive word of mouth and customer referrals which leads to profit maximization.
\end{abstract}

Keywords: Word of mouth, Pull marketing, Customer satisfaction, Banking sector.

\section{INTRODUCTION}

Firms strive to achieve success and remain viable in a business environment where competition has become so intense and customers very educating and aware of what exactly they need, and in the measure they want it. An organization seeking corporate growth must keep abreast the dynamism of today's business environment. A firm that is not achieving organizational objective is heading towards facing the very hard reality of winding up unless it realizes on time that the key to achieving organizational excellence is to satisfy profitable customers who in turn propagate and canvas for fellow customers to patronize such organization.

In marketing, it is believed that the best advertising is done by a satisfied customer who consciously and sometimes unconsciously becomes a crusader and a firm's advocate, influencing the views and opinions of potential customers concerning the firm's offering (Ahmad, Vveinhardt and Ahmed, 2014). In this article we state that customer satisfaction leads to increased profit resulting from positive word of mouth carried out by satisfied customers (Taghizadeh, Taghipourian, and Khazaei, 2013). This implies that a firm can only maximize profit when it adopts customer friendly policies that satisfy the customers who in turn give positive testimonies about the firm's product/ service offerings.

The customer is referred to as king in every marketing-oriented organization. The importance of customers cannot be overemphasized. Marketing success can only be achieved based on the number of profitable customers with an organization. It is no news that most marketing theorists have continually stressed the significance of customer satisfaction and the impact it poses on generating positive word of mouth referral from customers (Taghizadeh, Taghipourian, and Khazaei, 2013).

Positive word of mouth is of great importance particularly to the banking sector where most product offerings are largely intangible in nature and require personalized touch of customer service in order to generate positive comments from the customers. Previous researches on satisfaction and service quality revealed that the effect of a customer's past experience with a firm can be transferred and often influential on their attitude and behavioral responses towards the present encounter (Taghizadeh, Taghipourian, and Khazaei, 2013).Richins (2011) states that an organization should map out strategies that will generate positive behavioral intention (Word of mouth) as this is essential for achieving and sustaining organizational growth. 
Many corporate organizations today have realized the significance of delivering superior customer service, which leads to customer satisfaction. Hansemark and Albinson (2004) stated that satisfaction is an overall customer attitude towards a service provider, or an emotional reaction to the difference between customers expectation and what they actually receive, regarding the fulfillment of some needs, goals, or desire.

\section{THEORETICAL FOUNDATION}

This study draws its underpinning on word of mouth advertising and pull marketing theory. Word of mouth advertising is a marketing program that compels satisfied consumers to consciously or unconsciously give positive testimonies about a product experience on a non-commercial platform. Word of mouth could be referred to as the positive or negative influence of a person on the other. It is an oral person-to-person transmission of message which is often regarded as more powerful than a company generated message (Rathore and Panwar, 2016). Personal influence is prompted by a friendly conversation and is often seen as the most powerful tool firms use to improve positive word of mouth and reduce negative word of mouth because it is typical among trusted/ close friends (Kerin, Hartley and Rudelius, 2004). It is expedient to state that unlike viral marketing where consumers uses the online platform such as YouTube, Facebook, WasApp, Twitter, etc. to propagate a firm's product and may or may not have actually experienced the product, word of mouth advertising is done by a customer that have had a favorable or unfavourable experience/ contact with the firm's product offering. When an experience is favourable, it generates positive word of mouth and where the reverse is the case, it attracts negative word of mouth. However, the focus of this study is on positive word of mouth and profitability. Positive word-of-mouth is unpaid recruitment process by satisfied customers to potential consumers of such services. Firms use incentives and other inducement program coupled with quality of service offerings to entice customers into being advocates to potential customers.

\section{LiTERATURE REVIEW}

In today's over saturated markets, the key to achieving rapid growth and organizational success lies in the hands of satisfied customers. Satisfying the customer is pivotal to business growth because it makes the customer to be loyal to the firm's brand, leading to repeat purchase and generating positive word of mouth (PWOM). East, Hammond and Lomax (2008) defined Positive word of mouth as an informal advice given by a satisfied customer to a potential customer as regards a firm's products or services. The importance of personal referral on customer behaviour has regularly been buttressed by marketers. However, only a few numbers of companies seem to have harnessed the power of word of mouth and its relevance to organizations' performance (Buttle, 1998).

Promotional strategies used in creating awareness on a firm's product or service to the public are of two categories: push marketing strategy and pull marketing strategy (Paul and Donnelly, 2002). Push marketing is a strategy that gets the products directly to the customer; it puts the products in front of users so as to generate sales (Paul and Donnelly, 2002). Examples of push strategy include; Trade show promotions to encourage retailer demand, negotiation with retailers to stock the firm's products, packaging design to encourage purchase, point of sale displays, etc.

Pull marketing on the other hand gets satisfied consumers to bring potential users to the product (Paul and Donnelly, 2002). Firms use the pull marketing strategy to motivate satisfied customers to seek out their brands and make referrals to potential customers. Advertising and mass media promotion, word of mouth referrals, customer relationship management, etc. are examples of pull marketing strategy. Word of mouth (WOM) promotion is based on the principle of pull marketing. It involves the exchange of positive marketing message from one satisfied consumer to the other via conversation or personal communications such as email or text message (www.businesscasestudies.co.uk, 2015). Satisfied consumers that are excited about a firm's offering convey this excitement to family and friends, convincing them to try out the product/ service. Although push and pull strategy is mostly used in supply chain, it is also applied in other areas of marketing (Paul and Donnelly, 2002).

In this paper we define Positive Word-of-Mouth as:

a marketing program whereby a firm satisfies its customers and turn them into advocates (consciously or unconsciously), in a way that they spread good news to potential customers about the firms products/services. 
Positive word of mouth is an interactive function of both the firm and customers (Gremler, Gwinner and Brown, 2001). First, the firm endeavors to satisfy the customer who in turn becomes advocate for the firm. Positive word of mouth is a function of the satisfaction provided by the organization, and is customer-driven, leading to customer loyalty and repeat purchase. It is powered by the organization and driven by satisfied customers.

The power of word of mouth advertising cannot be overemphasized. In fact, it is seen as more effective than other forms of advertising such as radio and newspaper (Day, 1971 cited in Sweeney, Soutar and Mazzarol, 2005). In the words of Taghizadeh, Taghipourian, and Khazaei (2013), positive word of mouth is the most persuasive tool for diffusion and creation of awareness on new product innovation.

Banks that want to maintain favourable image should endeavor to reduce to the barest minimum or better still eliminate post purchase dissonance by providing satisfactory and differential services in order not to attract negative word of mouth (NWOM) from dissatisfied customers. The after effect of negative word of mouth could pose the danger of damaged reputation on firms, decreased customer traffic, loss of support from stakeholders, and loss of business opportunities (Blake- a contributor on azcentral.com).

Negative word of mouth poses a lasting damage on a firm's reputation as it reduces the possibility of a consumer to repeat purchase and also affects the attitude of potential consumers towards trying the product (Charlett, Garland and Marr, 1995; Richins, 1983).Most times this damage is difficult to repair and often metamorphoses into the customer taking legal action against such firm or complaining and discouraging potential users of the firm's products. There have been some arguments among scholars that NWOM and PWOM are similar except for the effect they pose on brand purchase intention (East, Hammond, and Lomax, 2008). East, Uncles, Romaniuk and Lomax (2016) opined that the thin line between negative and positive word mouth is that whereas the former poses more effect on the attitude and cognitive ability of customers, the latter influences mostly consumer purchase intentions.

The difference between positive word of mouth and negative word of mouth is a function of the level of satisfaction or otherwise a consumer derives from a firm's offering during each transaction. A satisfied customer would generate positive word of mouth about a firm's products; the reverse is the case for a dissatisfied customer. Therefore, a firm that wants to enjoy referrals from customers must provide satisfactory and differential services to customers.



Figure1. Study's conceptual framework

Through word of mouth communication the consumer community is abreast of current trends and the next big things are discussed among friends through word of mouth advertising (Zamil, 2011). Most marketing theorists have opined that satisfied customers share their experiences with other people (perhaps five or six people). On the contrary, dissatisfied customers are more likely to tell another ten people of their experiences with a particular corporation/ firm's products or services. A customer is said to be satisfied when his/her experience with a particular firm meets or better still exceeds expectation. Banks engage customers in positive word of mouth by offering them value for their 
money and high satisfaction that turn them into crusaders; making them to spread positive news about the bank and attracting prospective customers to the bank. This no doubt has been discovered as a strong weapon to fight competition and to increase profit maximization and subsequently enhance corporate performance in the banking sector in Port Harcourt.

Hughes (2005) has also argued that word of mouth is the most powerful form of advertising on earth, and that the power of conversation in marketing cannot be overemphasized. Little wonder most marketing theorists have said authoritatively that the power of word of mouth cannot be questioned (Sweeney, Soutar and Mazzarol, 2005).

It has been keenly observed that Word of mouth acts as a guide to consumer purchase intention and reduces the fears associated with trying out a new product as regards the customer's perceived value of that product (Olufemi and Dastane, 2016).

Customer perceived value is the cost-benefit evaluation and comparison of one product against the other by a potential customer.

When a product is discussed among friends and close associates prior to purchase, the risk of post purchase dissonance is reduced to the barest minimum.

However, one salient point to make here is that a marketer must bear in mind that positive word of mouth alone is not a guarantee for repeat purchase. Long-term customer loyalty depends on the level at which firm's product value exceeds customer expectations after making the first purchase. Contact staff should from time to time monitor the effectiveness of positive word of mouth, and where sales are no longer generated through customer referrals the satisfaction of customers should be improved (Sweeney, Soutar and Mazzoral, 2008). The implication is that a customer might have tried the firms' offering after being convinced by a fellow customer but his expectations were not met, and since the services rendered did not actually meet the expectations of the customer there was attrition after the first contact.

Many marketers are daily mapping out strategies to have a share of the customer's wallet. Lidely (2000) states that a richer understanding of the attitudinal component of loyalty is important and has been shown to be linked to future usage, thereby enhancing positive word-of-mouth (Reichheld, 2003), and ultimately leading to customer profitability (Reinarts and Kumar, 2002). Negative word of mouth (NWOM) can severely mar the reputation of a firm. A clear understanding of the danger it poses on the growth of an organization can help avert the unfavourable outcome of its effects on the company's image resulting from the negative utterances of the customers towards a company and its product offerings (East, Hammond, and Lomax, 2008; Blake- a contributor on azcentral.com). Appreciating the influence of word of mouth is significant to marketers' decisions on customer service, especially in the justification of expenditure on handling complaint emanating from past transactions, customer retention, and service recovery (Charlett, Garland, and Marr, 1995).

Liang and Wang (2007) stated that positive word of mouth communication is the manifestation that a customer is satisfied and delightful of the services provided by an organization, the result is that satisfied customers are retained and corporate performance such as: dependable market share, good image and reputation, and increased profitability is enhanced. This further shows that customer satisfaction exceeds the product's perceived values. The strategic application of word of mouth has led to the retention of old customers and attraction of new customers in the banking sector, leading to profit maximization.

Yi (1989) states that customer satisfaction as an attitude is like a judgment following a purchase decision or based on series of consumer product interaction. In the view of Zairi (2000) customer satisfaction leads to repeat purchase and customer retention. On the contrary, dissatisfied customers responds differently. They may try to reduce the dissonance by abandoning or returning the product, or by seeking information that might confirm its high value (Kotler, 2000). The quality of service delivery and satisfaction a customer derived from a previous encounter determines the bahaviour and attitude of a consumer, and whether or not a customer will stick to a particular bank (Zeithaml, Barry and Parasuraman, 1996). Therefore banks must constantly map out strategic programs aimed at satisfying the customers in order to gain a share of the customers' wallet, enjoy lasting customer loyalty and retention, experience customer referrals; and through these profit maximization is guaranteed. 


\section{Profitability}

Profit is usually defined as the residual of income in excess of costs of production or simply, revenue minus costs of production. Ezirim and Okon (2010) state that profit is often used to describe the surplus resulting from a definite trading period. In other words, it is a reward for engaging resources in condition of speculative risk for the satisfaction of consumer demand. It is in this context that definitions of marketing from different researchers end with a "profit". Because profit maximization is the rudiment of business transaction, this is not far fetch from corporate organization to measure good performances in business world.

Moro (2002), states that a firm is said to be making profit when its earnings from sales of goods are greater than production expenditures. Furthermore, total profit of a firm (TX) is the difference between its total sales revenue (TR) and total cost of production (TC): TX $=$ TR - TC. Therefore, profit maximization is the difference between the total revenue accruable from the sale of all outputs and the expenditure upon all inputs (Handerson and Guandt, 1930). The implication is that profit maximization maximizes the naira income of firm(s), since firms are considered as an economic institution; hence profit is regarded as a genuine way of measuring the performance of business.

Ezirim (2004), states that profit is defined in economic theory to be achieved either through cost minimization or output maximization or both. In the market place, it springs up through the channel of customer satisfaction which subsequently rewards firms with profitable and sustained patronage capable of boosting its profits. Although not all customers can be treated equally based on their level of contribution to the firm's profit, there are key account customers who appear to be major source of organization's sustenance (Hatem, 2007).

Researches have shown that profit contributions from customers can provide an important segmentation tool for an organization. Long term customers that have been retained over time provide the most reliable source of firms' future revenues and profits (Vogel, Evanschitzky and Ramaseshan, 2008; Lemon, Rust and Zeithaml, 2001). The above facts have made it glaringly clear that profit is a powerful tool for measuring organizational performance coupled with the delivery of friendly customer service and providing adequate reward to loyal and new customers.

Furthermore, generating positive word of mouth from satisfied customers should be the concern of all departments that make up the organization in order to have good interface between their target audiences and win them for long-term patronage, and profit maximization. It is noteworthy that firms that wish to remain viable and ever green in this dynamic business environment must constantly map out strategic programs capable of attracting and retaining new and existing customers respectively. Giving this, we state the alternate hypothesis below:

HA1: There is a significant relationship between positive word of mouth and Profitability in the banking sector in Port Harcourt.

\section{Methodology}

This study is correlational in nature, a macro analysis that involves test of hypothesis and quantitative methodology. The research was conducted on the twenty one deposit money banks in Port Harcourt and copies of structured questionnaire distributed to five top managers from each of the studied banks. Primary and secondary data were generated and hypothesis was tested with Spearman Rank Correlation coefficient (rh2) and regression analysis. In order to ascertain the level of consistency of the instrument, Cronbach's Alpha with a benchmark of 0.7 was used.

\section{ANALYSIS AND DisCUSSION OF FINDINGS}

The respondents to this study included 5 top management cadre employees from each of the 21 deposit money banks in Port Harcourt. Consequently, we distributed a total of 105 copies of questionnaire. 93 copies of questionnaire with $88.6 \%$ response rate were retrieved and usable while 12 copies with response rate $11.4 \%$ were either not retrieved or retrieved but were not useful due to incomplete or improper information provided.

We conducted a correlational test to know the relationship between variables.

The Spearman's correlation coefficient $(r)=0.533^{* *}$, this reveals a positive relationship between Positive Word of Mouth (PWM) and Profitability (P) in the banking sector in Port Harcourt. This implies that $53.3 \%$ variation in profitability is explained by Positive Word of Mouth carried out by satisfied customers. 
In the same vein, we did regression analysis on the variables to ascertain the nature of relationship (i.e. significant or otherwise).

Decision rule: If the Significant/Probability Value $(P V)<0.05$ (Level of Significance) $=$ Reject the null and conclude Significant Influence, otherwise conclude insignificant influence. Also, if t-calculated Value > t-tabulated, = Reject the null and conclude Significant Influence, otherwise conclude insignificant influence.

Consequently, the Probability Value $(\mathrm{PV})=0.03<0.05$ (level of significance). More so, $\mathrm{t}$-cal $=2.19>$ $\mathrm{t}-\operatorname{tab}(0.05,92)=1.96$. Therefore, we accepted the alternate hypothesis earlier stated that there is a significant relationship between Positive Word of Mouth and profitability in the banking sector in Port Harcourt. This findings, is in concordance with Buttle (1998) and Reinarts and Kumar (2002).

\section{CONCLUSIONS, IMPLICATIONS AND RECOMMENDATION}

1. From the result of findings it was concluded that there is a positive relationship between positive word of mouth and profitability.

2. We equally concluded that there is a significant relationship among the studied variables.

3. Also, we concluded that the study has both theoretical and practical implications:

- The theoretical implication of the study is that profitability is a function of positive word of mouth; i.e. $\mathrm{P}=f(\mathrm{PWM})$.

- The practical implication implies that positive word of mouth generated from satisfied customers will result to increased profitability of banks in Port Harcourt.

4. The study therefore recommended that banks in Port Harcourt should make customer satisfaction upper most in their service delivery so as to generate positive word of mouth referrals from satisfied customers which will in turn lead to increased and sustained profit maximization.

\section{SUGGESTION FOR FURTHER STUDIES}

The present study examined the nexus between positive word of mouth and profitability with emphasis on the banking sector's experience in Port Harcourt. We further suggest that similar studies be conducted on other sectors of the economy across Nigeria.

\section{REFERENCES}

Ahmad, N. et.al (2014).Impact of word of mouth on consumer buying decision.European journal of business and management 6(31). ISSN: 2222-2839

Blake, I.A. The impact of negative word of mouth. Retrieved from www.yourbusiness.azcentral.com [date retrieved: $26 / 10 / 2016$ ]

Buttle, F.A. (1998). Word of mouth: Understanding and managing referral marketing. Journal of Strategic Marketing 6(3). DOI: 10.1080/096525498346658

Charlett, D., Garland, R. \& Marr, N. (1995).How damaging is negative word of mouth? Marketing Bulletin, 6, 42-50, Research Note 1

East, R., Hammond, K. \&Lomax, W.(2008).Measuring the impact of positive and negative word of mouth on brand purchase probability.International Journal of Research in Marketing25(3), 215224 September.

East, R., Uncles, M.D., Romaniuk, J. \& Lomax, W. (2016).Measuring the impact of positive word of mouth and negative word of mouth a reappraisal. Australian marketing journal, 24(1): 54-58. DOI: 10.1016/j.ausmj.2015.12.003

Ezirim, A. \&Okon (2010). Dictionary of marketing: Mass communication and allied matters. Owerri: Trust Education Investment Company.

Gremler, D.D., Gwinner, K.P. and Brown, S.W. (2001).Generating positive word-of-mouth communication through customer-employee relationships. International Journal of Service Industry Management, 12(1), 44 - 59. DOI http://dx.doi.org/10.1108/09564230110382763.

Hansemark, O.C. \&Albinson, M. (2004). Consumer satisfaction and retention: The experiences of individual with employees. Managing service quality, 14(1).

Hatem, E.B. (2007). Focus on high profit growth potential. Journal of Marketing, 7, 79-93. 
Hughes, M. (2005).Buzz marketing: Get people to talk about your stuff. New York: Penguin group. Kerin, R.A., Hartley, S.W. and Rudelius, W. (2004).Marketing: the core. New York: McGraw-Hill. Kotler, P. (2000). Marketing management. New Jersey: Prentice-Hall.

Lemon, K.N., Rust, R.T. \& Zeithaml, V.A. (2001). What drives customer equity. Marketing management, 17, 10(1): 20-25

Lidely, A. (2000). Relationship marketing, loyalty programs and the measurement of loyalty.Journal of targeting measurement Analysis for marketing, 8(4), 351-362.

Link: www.businesscasestudies.co.uk. Engaging consumers through word of mouth marketing: a red bull case study [Date retrieved: 24/04/2017].

Olufemi, A.S. \&Dastane, O. (2016). The impact of word of mouth on customer perceived value for the Malaysian restaurant industry. The East Asian journal of business management, 6(3): 21-31.

Paul, P.J. \& Donnelly, J.H. (2002).A preface to marketing management. New Jersey: McGraw-Hill.

Rathore, S. and Panwar, A. (2016).Capturing, analyzing, and managing word-of-mouth in the digital marketplace.USA: Business science reference an imprint of IGI Global.

Reichheld, F. (2003). The one number you need to grow. Harvard Business Review, 81(12), 46-54.

Reinartz, W. J. \& Kumar, V. (2002). On the profitability of long-life customers in a Non-contractual setting: An empirical investigation and implications for marketing. Journal of marketing, 64 (October), 17-35.

Richins, C. (2011). The influence of staged experiences on delightedness and behavioral intentions. M.Sc. Thesis, Departmnet of Parks, Recreation and Tourism, the University of Utah.

Richins, M.L. (1983). Negative word of mouth by dissatisfied customers: a pilot study. Journal of marketing, 47(1).Published by AMA. DOI: 10.2307/3203428

Sweeney, J.C., Soutar, G.N. \& Mazzarol, T. (2005).The difference between positive and negative word of mouth - emotion as differentiator?ANZMAC 2005 conference: consumer behavior.

Sweeney, J.C., Soutar, G.N. \& Mazzoral, T. (2008). Factors influencing word of mouth effectiveness: receiver perspectives. European journal of Marketing 42(3/4).Emerald group publishing Ltd.

Tse, D.K. \& Wilton, P.C. (1988).Models of consumer satisfaction formation: An extension. Journal of Marketing Research, 25(2) May, 204-212.American Marketing Association. URL: http://www. jstor.org/stable.

Vogel, V., Evanschitzky, H. \&Ramaseshan, B. (2008).Customer equity drivers and future sales. Journal of Marketing, November.

Yi, Y. (1989). A critical review of a consumer satisfaction review of marketing. V.A. Zaithaml, Chicago, American marketing association: 68-123.

Zairi, M. (2000). Managing customers satisfaction: A best practices perspective. The Tom magazine, 12(6), 389-494.

Zamil, A.M. (2011). The impact of word of mouth (WOM) on the purchasing decision of Canadian consumers.Research journal of international studies - issue 20 September. www.researchgate.net

Zeithaml, V.A., Berry, L.L. \& Parasuraman, A. (1996).The behaviouralcosequences of service quality. Journal of marketing 60(2), 31-46.

\section{AUTHOR's BIOGRAPHY}

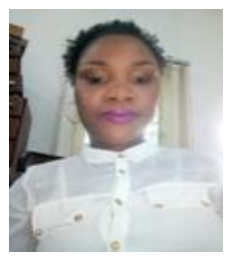

Bright ZorBari-Nwitambu, hails from Yae community in Khana Local Government Area (Ogoni) of Rivers State, Nigeria and works in the Library Department of Ken Saro-Wiwa Polytechnic, Bori. She is currently pursuing a Ph.D in Marketing at the University of Port Harcourt, Port Harcourt- Nigeria. She is happily married to Mr. ZorBari Nwitambu with a Son Master M-ereBari Majesty ZorBari-Nwitambu. 